\title{
Fernando Costa Andrade: poeta angolano em luta
}

Vera Lúcia de Oliveira*

* Universidade de Estudos de Lecce, Itália. 
Fernando Costa Andrade, importante poeta angolano, é um lírico militante. Poeta e homem se confundem, a poesia irrompe do empenho e o empenho nasce da poesia numa quase absoluta reciprocidade e identificação. Falo de amor por amar $^{1}$, o título de um dos seus últimos livros, pode ser lido neste sentido como uma declaração de poética, uma chave para interpretar este universo feito de força e delicadeza. A sua poesia é, em sintonia com as feridas e angústias da África, comprometida civil e politicamente, mas que não abdica da esmerada pesquisa formal e estética.

Veremos aqui como não é possível isolar a obra deste poeta do amplo contexto da sociedade angolana. U ma interpretação que a alienasse desse universo seria não só incompleta, mas mutiladora. Isto ocorre porque a poesia de Costa Andrade adquire o seu pleno significado a partir das circunstâncias históricas que a condicionaram, da urgência dos fatos que solicitaram dos escritores angolanos um determinado tipo de poética, com uma função específica: a de ser arma de luta social e política.

Ora, se toda obra de arte está de um modo ou outro vinculada ao próprio contexto social, para os poetas engajados, no caso Costa Andrade, a estrutura social não apenas se impõe no momento da criação artística com o seu específico universo de valores, mas condiciona prepotentemente a própria configuração temática e estilística do texto. $O$ contexto é sentido como o primeiro movente da obra: informa não só sobre a temporalidade do texto; é, num certo sentido, também texto. 
A obra de Costa Andrade afunda suas raízes no continente africano, é angolana até o paroxismo; completamente comprometida com o processo histórico de restituição da soberania a este país marcado por um colonialismo que repetiu ali, como por toda parte, seu paradigma opressivo. Mas se em sua poesia lemos a história recente do próprio país, nela a história interseca-se e confunde-se com as experiências e a vivência pessoal do poeta: a clandestinidade, o exílio, a prisão, a visão dos tantos mortos, a adesão à guerrilha e a participação na luta pela independência. Os sentimentos alternam-se: dor, raiva, esperança. A língua ajusta-se ao esforço de modelação, na poesia mais indignada como naquela delicadíssima de amor ou paixão.

Como outros escritores angolanos, o autor cria ritmos e cadências novas na língua portuguesa, amolda a língua à necessidade de transformá-la de código lingüístico da colonização em código lingüístico da angolanidade, instrumento idôneo para veicular a literatura de uma nova nação. Vocábulos das línguas locais, línguas banto (kimbundo, umbundo, kikongo, cokwe, etc.), são incorporadas com grande naturalidade em toda a sua obra. Existe de fato uma significativa geração de escritores angolanos empenhada a fundo na criação de um idioma literário nacional. Desapareceu da obras destes autores aquela apropriação lingüística de caráter exótico e folclórico dos idiomas africanos que caracterizava a precedente literatura colonial. Não é ousado supor que em Angola ocorrerá o que já aconteceu no B rasil: o português assumirá semblante novo, se adaptará a culturas diferentes, se transformará numa verdadeira variante idiomática da língua portuguesa. "A linguagem evolui, atualiza-se, arma-se", nas palavras de Manuel Ferreira, para exprimir conteúdos novos².

E os novos conteúdos surgem da ótica diversa, invertida, com a qual estes intelectuais procuram reler a história: a partir de sua angolanidade, de suas raízes fincadas na África, continente de homens com difíceis perspectivas de futuro, de homens vistos desde sempre como desprovidos de história (já que a história é codificada pelos vencedores). Costa Andrade identifica-se com estes homens e com seu esforço e desejo de resgate. E a necessidade de ser parte integrante da história, de ser nela agente ativo é, neste caso, um repercorrer a estrada em busca de si mesmo, um recuperar os próprios valores culturais e uma especificidade que é angolana, africana. O fundamento do sistema colonial é justamente o de induzir o colonizado o ver e perceber seu mundo como periférico. Pois bem, Costa Andrade, como outros poetas comprometidos contra esta secular marginalização, apropriase de um código lingüístico e literário que é ao mesmo tempo europeu e angolano 
para inverter este ponto de vista, para trazer a gala esta outra parte de poesia que nasce de quem deve combater para ter poesia.

\section{“Não há sonho com mais asas \\ que o sonho encarcerado."3}

E stes versos, escritos nas prisões da ditadura militar brasileira ( o poeta achava-se no B rasil como representante do M ovimento de L ibertação de Angola quando estourou o golpe de estado de 1964), reconduzem-nos à nossa proposição inicial e ao explicitar-se da poética de Costa Andrade: "Falo de amor porque amo", falo de liberdade porque pratico a liberdade, porque a busco constantemente. E o que é poesia, senão palavra, verbo que pode nascer também nas prisões e das prisões, mas que é liberdade, ou não é poesia. J ustamente a coerência a esta concepção poética o levará a engajar-se concretamente nas hostes do M ovimento Popular de Libertação de Angola.

Costa Andrade é um poeta que assume completamente a própria condição de poeta angolano, ou seja de poeta que, pelos condicionamentos da história, deve ser sobretudo poeta nacional e social: "a poesia de hoje é a voz do povo" ${ }^{4}$. E o homem angolano, naquele momento dramático do seu percurso histórico ligado à luta pela independência, podia conceber somente poemas de dor e raiva, de angústia e de luta contra a marginalização que sofria:

\footnotetext{
Verso que em mim possa haver

é a minha raiva contida

verso que em mim possa haver

tem a cor do sangue da raiva. ${ }^{5}$
}

Costa Andrade nasceu em Lépi (Huambo), em 12 de abril de 1936. Passou a infância naquela província do planalto central angolano, na propriedade agrícola do pai. Sua formação é eclética, africana e européia ao mesmo tempo, fruto de muitas horas passadas entre os clássicos da biblioteca paterna e as estórias africanas narradas em umbundo pela avó materna, que mal falava o português. Este binômio cultural, esta dupla e simultânea fonte de informações e de influências caracterizarão as opções futuras do poeta. Mas estas características são próprias também do universo angolano, feito de imbricamentos culturais, de sincretismos

\footnotetext{
“Cela 1", in Fernando Costa Andrade, Poesias com armas, Lisboa, Sá da Costa, 1975, p.42.

"A flor da chuva", in Fernando Costa Andrade, Poesia com armas, cit., p.26.

"A voz da terra", in Fernando Costa Andrade, Ontem e depois, Luanda/Lisboa, União dos Escritores Angolanos/E dições 70, 1985, p.17.
} 
freqüentemente lacerantes, de problemáticas para as quais a sociedade busca com fadiga soluções.

Desde cedo o poeta entra em contato com os conflitos étnicos que marcam há séculos, e dramaticamente, a África. Filho de pai português e de mãe mestiça, o poeta é, ele próprio, sinal vivente daquele conúbio étnico e cultural condenado pela comunidade branca, que mal suportava os matrimônios mistos. A madurece nela a consciência de que se encontra num cruzamento de mundos diversos: "N asci igual a uma mensagem / com raízes em todos os continentes..." 6 . Ao mesmo tempo, ele amadurece a sua opção coerente e profunda pelo universo africano.

E m 1955, entra em contato pela primeira vez com expoentes da geração de Mensagem, revista que era porta-voz do "M ovimento dos Novos I ntelectuais de Angola". Da revista foram publicados apenas dois números em L uanda, em 1951, mas foram suficientes para provocar uma verdadeira revolução no panorama literário nacional. Mensagem tornou-se um símbolo para as gerações sucessivas de escritores e intelectuais: é a partir dela que nasce a moderna poesia angolana e a consciência da angolanidade ou, em outras palavras, a reivindicação de uma identidade cultural e nacional. A derem Agostinho N eto (1922-1979), António J acinto (1924), Viriato da Cruz (1928-1973), M ário Pinto de Andrade (1928), Mário António (1934) e outros.

Costa Andrade procurará conhecer a produção dos intelectuais de Mensagem, estabelecendo com os mesmos uma imediata identificação. A leitura da poesia "O grande desafio", de António J acinto, abrir-Ihe-á novos horizontes literários e políticos. Todavia, não foi fácil o contato com os escritores do grupo, pois muitos deles já estavam na clandestinidade.

U ma outra etapa importante da sua maturação poética foi o período de estudos que transcorrerá em Portugal, a partir de 1957. E m L isboa, encontra um clima de intenso ativismo político e cultural, e instaura relações de amizade e de colaboração com os intelectuais angolanos empenhados na resistência ao colonialismo. A sua adesão a tais instâncias nacionalistas é total: dela vem, segundo o próprio poeta, o abandono da precedente literatura por ele definida como "camoniana" 7 , da qual se tinha nutrido até então. Dedica-se ao estudo dos poetas da négri tud, Senghor e Cesaire, dos escritores do neo-realimo português, dos brasileiros J orge Amado, Graciliano Ramos, M anuel $B$ andeira, dos grandes poetas revolucionários de todos os tempos, como Guillén, Neruda, M aiakovski, Lorca, Éluard, todos fundamentais para sua formação. O próprio conhecimento da cultura africana e de muitos escritores angolanos (e entre estes Agostinho N eto e António J acinto são talvez os que mais o influenciaram) intensifica-se em Portugal.

"Mulato", in Ontem e depois, cit., p.28.

Entrevista realizada por Rosa Correia, Luanda, agosto de 1988 
Graças a esta febril atividade de leitura, o poeta alarga o seu universo cultural, poético, humano. Nascem, neste momento, os poemas que serão reunidos com o título Indecisão, onde Costa Andrade, como afirma Mário Pinto de Andrade, “nesta fase do seu enraizamento cultural e de 're-africanização' do seu espírito, inicia a fixar, exaltando-o, o mundo do sofrimento popular"8.

O poeta continua, entretanto, o seu curso universitário de arquitetura e participa ativamente das iniciativas da CEI , a "Casa dos Estudantes do I mpério", que - criada em meados dos anos quarenta em Lisboa - exerceu um papel importante na agregação de estudantes, escritores e intelectuais africanos. O poeta foi um dos diretores da mesma, organizando com Carlos E verdosa, em aberto desafio às autoridades portuguesas, a publicação de escritores inéditos ou postos sob censura, entre os quais Agostinho Neto.

Em 1960, retorna a Angola por um breve mas fecundo período. Renova o contato com os principais expoentes de Cultura, revista que, na mesma linha de Mensagem, continua a revelar os novos valores dos intelectuais angolanos. Fundada em 1945, e fechada logo a seguir, Cultura reaparece em 1957. Costa Andrade adere à mesma ao lado de L uandino Vieira, António Cardoso (1933) , Ernesto Lara Filho (1932), Arnaldo Santos (1936) e outros.

O poeta aprofunda a sua imersão na cultura e no mundo africano: a terra e o homem deste continente tornam-se elementos centrais em sua obra. Sua voz poética afina-se e harmoniza-se a este universo, buscando uma sempre mais pura e consciente identificação. Nascem os primeiros livros, Terra das acácias rubras e O capim nasceu vermelho:

Eu sei irmão que a tua dor
não posso avaliá-la exactamente
mas nasci com um caminho igual ao teu.

Isso me basta

para sentir na carne

as feridas que tu sentes e os anseios. ${ }^{9}$

De novo em Portugal, ali permanecerá até 1961, ano em que será obrigado a deixar clandestinamente o país em virtude de suas atividades culturais e políticas (era procurado pela PIDE, a polícia secreta do governo português) ${ }^{10}$.

\footnotetext{
Mário Pinto de Andrade, “O canto Armado do Povo Angolano”, in Costa Andrade, Poesia com armas, cit., p.3.

"A voz da terra", in Ontem e depois, cit., p.18.

O poeta partiu de Lisboa na noite entre 30 de setembro e 1 de outubro de 1961. A experiência desta difícil viagem é narrada na “Poesia 1" do livro Tempo angolano em I tália, pp.77-83.
} 
Costa Andrade inicia um período de exílio de sete anos, com períodos de permanência mais ou menos Iongos em diversos países, como B rasil, Itália e Iugoslávia. Faz conferências e recitais por toda a E uropa, buscando adesões de organizações e governos à luta contra o colonialismo: em 1961 iniciara a guerra em Angola.

No Brasil, retoma os estudos de arquitetura e continua a atividade de sensibilização em favor da luta angolana. O dramático golpe de estado de 1964, com a deposição do presidente J oão G oulart, surpreende-o em São Paulo e o poeta é preso e expulso do país. Do Brasil ele voltará à Itália, depois à Argélia e à I ugoslávia, de onde partirá - interrompendo novamente os estudos - para participar diretamente da guerrilha angolana.

Os anos entre 1967 e 1974 são vividos nas florestas da Angola Oriental, como guerrilheiro do MPLA, o "Movimento Popular de Libertação de Angola”. Depois da independência, participa ativamente da reconstrução do país, com importantes cargos no novo governo.

Costa Andrade é um intelectual verdadeiramente eclético. Escritor, pintor, crítico e jornalista, passa das artes figurativas à palavra com grande desenvoltura. Nunca deixou de escrever, não obstante a vida errática e aventurosa. Suas obras acompanham, de fato, este atormentado percurso humano. Primeiro a consciência da própria condição de poeta africano, depois sua adesão a tal condição, adesão que se radicaliza quando a guerra em Angola se faz mais áspera e exige a participação direta de todos os angolanos. Numerosas são portanto as obras em prosa e poesia, embora seja bastante difícil estabelecer com exatidão, como veremos, a cronologia deste percurso literário.

Poemas e contos de Costa Andrade aparecem hoje em várias antologias publicadas em Angola, Portugal, Brasil, Argélia, França, Itália, Quênia, Rússia e ex-I ugoslávia. É um dos membros fundadores da União dos Escritores Angolanos, da qual foi o primeiro secretário.

Seguir cronologicamente o percurso poético de Costa Andrade é tarefa que se revela por vezes ingrata, sobretudo porque muitas das suas obras foram publicadas de maneira precária e provisória, em jornais, revistas, antologias coletivas de autores africanos, em edições às vezes clandestinas e artesanais. Isto se deve seja à precariedade da condição de exilado político, que por bem sete anos se viu obrigado a deslocar-se de um país para outro, seja à própria participação na luta armada. O autor confessa, aliás, ter dificuldade em estabelecer uma ordem para sua produção.

Quero agora... confessar a minha enorme dificuldade de realizar - escrever - a minha cronologia literária, devido à completa desorganização do meu fichário pessoal. De fato, não 
me lembro mais das datas e às vezes nem dos títulos de trabalhos e conferências que fiz pelo mundo, de forma não muito sistemática. Foi uma vida de lutas, de saltimbanco, e tive de recomeçar pelo menos três vezes, a partir do nada, minha casa. Deixei centenas de livros e objetos, notas, escritos, desenhos e agendas, em pelo menos cinco países ${ }^{11}$.

Como ocorreu com outros escritores da sua geração, também no caso de Costa Andrade, numerosas obras - algumas já conhecidas em vários países europeus mas quase desconhecidas em Angola - foram publicadas dentro de poucos anos, de 1975 a 1979, pela União dos E scritores Angolanos, que depois da independência assumiu diretamente o empenho de divulgar os seus mais representativos escritores. E m diversas edições e reedições, saíram cerca de trezentos e cinqüenta mil livros ${ }^{12}$, número notável para um país com uma porcentagem muita alta de analfabetismo ${ }^{13}$.

Procurou-se desta forma recuperar, orgânica e sistematicamente, todo o material disperso, obras em muitos casos consideradas pedras miliárias de tal literatura. Todavia a diáspora dos escritores e a dispersão de suas obras foi tão relevante que ainda hoje pode ocorrer que se encontre textos citados pelos críticos mas não publicados em livro e de não fácil individualização.

Vejamos, a tal propósito, um exemplo: o livro Canto de Acusação de Costa Andrade foi citado por vários estudiosos. Mário Pinto de Andrade faz da obra uma sucinta análise, incluída no prefácio de Poesia com armas ${ }^{14}$. Alfredo Margarido cita-o como exemplo entre os mais significativos de poesia profética e de combate que caracterizou a literatura angolana durante os anos da guerra de independência ${ }^{15}$. A crítica Fernanda Toriello traduz em italiano partes do Canto de Acusação para a antologia Poesia Angolana Moderna, publicada na Itália em $1981^{16}$. Poemas deste livro foram traduzidos e publicados em muitos países e estão entre os mais conhecidos do autor. Segundo informações fornecidas por diversos críticos

11 Comunicação pessoal do autor (8 de agosto de 1989).

12 Cf. Helena Riaúzova, Dez anos de Literatura Angolana, Luanda/Lisboa, União dos Escritores Angolanos/E dições 70, 1986, p.12. Afirma a autora: “Fundada em 10 de dezembro de 1975 (um mês depois da declaração de independência), a União dos Escritores Angolanos teve até 1979 uma atividade editorial realmente impressionante... E dições de três a seis mil exemplares - e de vinte a cinqüenta mil nas edições econômicas - esgotaram-se em poucas semanas e praticamente só na cidade de Luanda."

13 Durante o período colonial era extremamente árduo para um angolano o acesso aos estudos regulares. Foi o M PLA, já durante a guerra de libertação, a promover as primeiras campanhas de alfabetização, graças às quais hoje o número de alfabetizados è de $30 \%$ da população. Todavia, não podemos esquecer que em Angola só uma minoria - $20 \%$ da população - tem o português como língua mãe. Cf. Pilar Vasquez Cuesta, “O ensino do português enquanto língua segunda em Angola", in Angolê - Artes, Letras, I dei as, Odivelas, n.1, 3/90, pp.15-18.

14 Mário da Silva Brito, "O Canto Armado do Povo Angolano", cit., pp.7-18.

15 Alfredo Margarido, Estudos sobre Literaturas das Nações Africanas de Língua Portuguesa, Lisboa, Ed. A R egra do J ogo, 1980, p.372.

16 Fernanda Toriello, Poesia Angolana Moderna, B ari, Adriatica, 1981. 
poder-se-ia formular a hipótese que a obra contivesse originalmente pelo menos quatorze poemas razoavelmente longos: Mário Pinto de Andrade, no prefácio a Poesia com armas, cita os três versos finais do livro Canto de Acusação, versos que pertenceriam ao "Poema décimo quarto" da referida obra. Ora, em uma entrevista registrada em $L$ uanda em agosto de 1988, o poeta afirma que inicialmente o livro era formado por cerca de quarenta textos. Sucessivamente, numa comunicação pessoal de 19/11/1989, afirma que o mesmo livro tem vinte e sete poesias. E videntemente, ao longo dos anos, o autor continuou a reorganizar o volume e a selecionar os poemas.

A questão que formulamos agora é a seguinte: o livro Canto de Acusação chegou a ser publicado integralmente? Sabe-se da publicação em Angola de nove dos seus poemas, cinco em Poesi a com armas e quatro em Ontem e Depois, estes últimos na seção denominada genericamente "P rimeiros Cadernos". Tudo parece indicar que o poeta tenha aos poucos desmembrado o livro, operação que se deve talvez à impossibilidade de publicá-lo na íntegra dadas as precárias condições em que vivia. A seguir recolheu, em Ontem e Depois, os poemas que haviam ficado inéditos e que ele ainda considerava válidos. Canto de Acusação não foi portanto nunca publicado em sua globalidade e talvez nem mais o será, pois o poeta em 1985, com o livro Ontem e Depois, afirmou ter concluído a divulgação dos textos poéticos escritos no período dos vinte anos que precederam a Independência angolana ${ }^{17}$. $\mathrm{E}$, no entanto, Costa Andrade é conhecido em muitos países sobretudo pelos poemas deste livro, textos que pela alta tensão estética, pela mensagem de que são porta-vozes, colocam-se entre os momentos mais altos de toda a sua obra.

Este é somente um dos problemas que se encontram analisando a obra do poeta. Também as datas e as informações são freqüentemente contraditórias e incompletas. Esta estranha intangibilidade do corpus da obra de Costa Andrade parece ser uma prerrogativa não apenas literária. Também o autor é esquivo neste seu peregrinar, primeiro fora do país e depois pelo interior da Angola. Precisou, por razões óbvias, disseminar vestígios, sinais diversos de si e de sua produção, deixando uma série de lacunas hoje dificilmente preenchíveis. É um percurso poético fugidio, condicionado pelas várias vicissitudes pessoais (leia-se "nacionais"), de tal forma que é bastante árdua a tarefa de recompor as tesselas do mosaico literário sem recompor também o homem.

Tudo isso contribuiu para intensificar a atmosfera um tanto profética e misteriosa que circunda boa parte de sua poesia, textos cuja literariedade é por vezes sacrificada em função do engajamento e da luta política. A poesia de Costa Andrade parece ser o resultado desta íntima conversão àquilo que o autor considera uma

17 Cf. Ontem e Depois, texto de capa. 
missão: a de fazer do próprio canto uma arma de luta. Nesta obra-missão, o poeta não existe como individualidade, como ente específico, mas existe só em função do seu povo e da luta deste povo. A própria poesia não se concretiza apenas como texto, como signo abstrato, mas é poesia-para, poesia-arma, poesia-voz coletiva, canto da indignação de uma nação inteira diante da marginalização que sofre, do sofrimento e da miséria de tantos, do heroísmo dos que caíram na luta.

\author{
J untei na mão \\ os meus poemas \\ e lancei-os ao deserto \\ para que as areias \\ se transformem em protesto. \\ Sejam catanas armas ou punhais \\ sejam protesto. ${ }^{18}$
}

Quais são as recorrências temáticas e estilísticas da poesia de Fernando Costa Andrade ou, em outras palavras, suas isotopias formais e de conteúdo? Vimos que ele é um lírico militante: percorrendo seus livros percebe-se que o fulcro de grande parte de sua obra é o empenho - ético e social - contra o colonialismo e contra o racismo, sob quaisquer bandeiras se manifestem. Ao mesmo tempo, ao lado desta poesia que é arma e denúncia, encontramos um delicado lirismo amoroso, que se evidencia em muitos livros, mas que o poeta, em plena guerra, sente que deve sufocar (e sente-o com grande pesar):

“...e se alguma vez pudeste adivinhar na firmeza do negar-me que me imponho

(...)

Em mim nasceu o que não pode ser vivido porque eu sou o resultado de impossíveis a distância maior entre as linhas tão suaves"19

O "Poema primeiro de um canto de acusação" é, neste sentido, um dos textos mais significativos: poesia sobre a poesia de amor que não pode ainda nascer, que não pode germinar porque as condições históricas em Angola e na África não o consentem. Lê-se nestes versos a dor sentida do poeta que deve, em função das circunstâncias históricas, transformar o próprio lirismo em “um canto que acuse e

18 "Motivo", in Poesia com armas, cit., p.21.

19 "Insônia", in Poesia com armas, cit., pp.51-53. 
cante / acuse os homens e cante / cante e acuse / com os dedos apontados para o norte" 20

Se tivesse vivido num momento ou num contexto histórico e geográfico diverso, qual teria sido a poesia de Costa Andrade? Teria o poeta explorado outros filões, desvendado outras dimensões nele latentes? A firma-se com freqüência que não existe poesia engajada: existe a poesia em si, e existe o empenho por uma determinada causa. E é assente o fato que o poeta comprometido sacrifica muitas vezes o texto em nome de suas convicções e de sua luta. Todavia, nem sempre um poeta pode escolher o tipo de poesia que desejaria. Homem sensível, ele não consegue viver a realidade da guerra, da miséria humana, da dor, sem participar dos dramas que o circundam. O poeta que não vivesse o seu tempo seria um indivíduo sem história, sem laços com os contemporâneos. E que poesia poderá nascer da indiferença?

A formação de Costa Andrade dá-se num momento dramático para a Angola, momento em que toda a sociedade lutava para resgatar sua identidade, para promover a unidade nacional e reivindicar a soberania. Não nos esqueçamos que o poeta nasceu em 1936, e que foi justamente a partir de 1940 que se intensificou em Angola o processo de tomada de consciência de toda a sociedade, processo que irá desembocar, graças à repressão que sofreram seus promotores, na clandestinidade da guerrilha e depois na guerra.

É natural que ele seja envolvido e arrastado por estes acontecimentos e pela urgência histórica de posicionar-se publicamente. A luta armada contra o domínio português, iniciada em 1961, prosseguiu com fases alternadas de recrudescimento e de estagnação até 1975, ano da independência angolana. A sua poesia colherá este momento de resistência, procurando incidir sobre a realidade.

Exemplo eloqüente do necessário pragmatismo dos seus versos é o livro 0 Cuneme corre para o sul, escrito em apenas cinco dias e imediatamente publicado, em setembro de 1981, "para constituir-se em gesto concreto de solidariedade e de agradecimento ao sacrifício dos jovens combatentes angolanos que pagavam com o heroísmo e com a vida a fúria assassina dos sul africanos"21.

Costa Andrade, todavia, não inicia a própria obra como poeta militante, poeta da guerrilha, embora já a partir dos primeiros poemas e contos lemos adesão e solidariedade ao mundo africano. O fulcro desta lírica é a África, sua geografia física e humana, sua história. Sob o impacto e a influência da Negritude, o universo africano é exaltado nos seus valores, ao mesmo tempo em que se buscam as raízes históricas da marginalização e da exploração do homem negro. Temos de

20 “Poema primeiro de um canto de acusação", in Poesia com armas, pp.29-30.

${ }_{21}$ Comunicação pessoal do autor (20 de janeiro de 1990). 
forma bem evidente em Terra das Acácias Rubras, o primeiro livro publicado, a participação comovida do poeta aos tantos pequenos dramas quotidianos, às histórias anônimas e trágicas que ele procura resgatar através da poesia.

Neste ínterim, os acontecimentos precipitam-se, a violência degenera, miIhares são os mortos em Angola. A sua poesia, influenciada por tais fatos, se fará pungente denúncia da indiferença do mundo ocidental aos massacres que estavam ocorrendo. Talvez este seja um dos seus momentos mais intensos. A indignação do poeta acomete e arrebata a linguagem poética como um dique aberto, modela-a, transforma-a em arma capaz de ferir a sensibilidade até dos mais indiferentes. Nesta fase, enquadram-se os livros Poesi a com Armas e Ontem e Depoi s.

Em 1967, Costa Andrade entra na guerrilha. Desta experiência surgirão os poemas militantes propriamente ditos, cujo pano de fundo é a guerra, as emboscadas, as dificuldades da vida distante de amigos e familiares, os dias passados a contar os mortos depois de cada batalha; e o pranto pelos heróis, a raiva contra os que se opunham ao seu sonho de liberdade. Manuel Rui definiu esta fase épica, afirmando que o livro Poesia com Armas "é o maior documento épico da primeira guerra de libertação"22. E nquadram-se nesta fase também os livros O Caderno dos Heróis e O Cunene corre para o sul. E ste último, historicamente, refere-se à invasão da Angola por parte da Á frica do Sul, mas não se distancia dos outros quanto à forma.

A adesão à luta e à guerra provoca porém profundas lacerações em Costa Andrade, contradições insanáveis entre a aversão, a repugnância à violência e a necessidade contingente da luta:

\footnotetext{
Eu não inventei os aviões nem construí os aeroportos apenas me senti discriminado homem sem sombra a quem roubaram a juventude e os ecos.
}

\footnotetext{
Eu vou partir pagar um preço para ser homem igual ao mundo ${ }^{23}$
} 
Mas quem pode optar impunemente pela guerra, quem pode ser feliz por tal escolha? A poesia desta fase é um esforço de esmiuçar, elaborar, compreender tal contradição, de lembrar e de lembrar-se a cada momento o porquê da violência, tanto a que ele sofre quanto a que deve infligir.

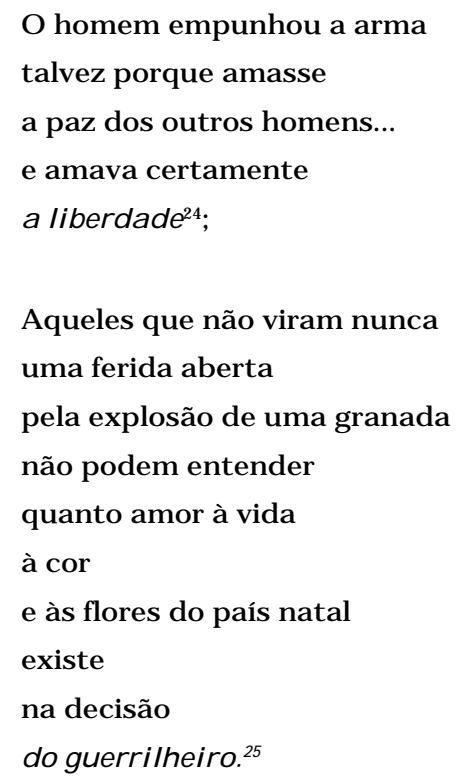

E na poesia, cujo título emblemático é “O Futuro nasceu da noite", o poeta reafirma:

Era preciso rasgar a noite era preciso rasgar a noite! A punhalar a escuridão com um verso de sangue incoagulável.$^{26}$

Colhe-se aqui toda a angústia do poeta (sublinhada pelo paralelismo dos versos), ao lado da revolta impotente, gerada pelo inelutável da violência contra a violência, "a noite" que é necessário romper e lacerar.

Os recursos retóricos privilegiados estão relacionados a esta poética do necessário, são condicionados por este pragmatismo. Costa Andrade utiliza com freqüência a repetição: palavras, versos, às vezes inteiras estrofes iteram-se em toda a sua obra. As estruturas paralelísticas têm um evidente valor enfático, além 
da função de concentramento de significados, de enriquecimento conotativo dos termos e do texto em si.

Uma outra figura retórica muito empregada é o anacoluto. O poeta parece distribuir, jogar as palavras no texto sem uma aparente conexão entre elas, como se repetisse o gesto de quem semina o grão no solo. A distribuição irregular dos versos no espaço branco e o descontínuo espaçamento dos mesmos na página reforçam a imagem da seminação. O anacoluto contribui para uma certa substantivação da palavra, que perde sua função na estrutura sintática da frase e adquire, no verso, um outro tipo de conexão com os elementos de uma diversa e mais complexa estrutura. Em Costa Andrade, como se disse, a palavra é arma, pedra, objeto contundente, é semente que ele esparge na página para que produza consciência e vida.

Do ponto de vista formal a radicalização da sua opção política e poética traduz-se numa linguagem sempre mais vibrante e veemente. As imagens simplificam-se, as construções sintáticas fazem-se lineares, aproximando-se da organização mais didática da prosa. O poeta busca uma comunicação direta, sem filtros de metáforas, com o leitor.

Costa Andrade acentua a tendência ao abandono dos elementos alegóricos, artifícios estilísticos do passado, e reorganiza a linguagem da poesia militante em torno de imagens que falam literalmente à imaginação e à memória dos destinatários ${ }^{27}$.

Ora, a poesia comprometida vive, mais do que qualquer outra, num precário equilíbrio: o poeta tende a concentrar-se prevalentemente sobre a intencionalidade da linguagem, sobre a função que J akobson define denotativa. O código poético sofre muitas vezes, nesta operação, uma perda de intensidade. Num certo sentido, como vimos, o poeta sacrifica o texto à causa que lhe parece mais urgente. Muitos grandes poetas e escritores viveram e vivem esta dialética, abertura ou fechamento do discurso poético aos acontecimentos da história, empenho ético ou estético. 0 equilíbrio é difícil e não é sempre que se consegue atingi-lo com eficácia.

No caso de Costa Andrade, vemos que alguns dos momentos mais altos da sua poesia até hoje publicada identifica-se justamente com a produção engajada. O livro Poesi a com armas permanece uma das obras significativas da poesia angola, livro definido por Mário Pinto de Andrade como o "canto armado do povo angolano". Os textos de Canto de Acusação, uma das seções do livro, alcançam aquela feliz síntese entre poesia que quer intensamente "falar" aos contemporâneos e código lingüístico que é sempre e ainda aquele estético. 
Contudo, não toda a obra de Costa Andrade desta fase combativa alcança uma tal síntese. Parte dela perde intensidade, poeticidade, mesmo quando a sua função predominante, aquela pragmática de denúncia e de luta, alcança o objetivo prefixado. Se o nosso fosse um estudo sociológico ou ideológico do texto, seguramente tal aspecto deveríamos relevar: a importância da obra e da figura do poeta na própria definição do conceito de "angolanidade", sua coerência íntima entre vida e obra, seu sacrifício pessoal na luta contra o colonialismo e o racismo. M as a nossa é um análise literária, e é a literariedade da obra o objeto desta leitura, embora isto não exclua a consciência de que a literatura não existe como fenômeno em si, sem correlação com o contexto; ela é parte de um todo, a sociedade, dentro da qual é concebida e fruída.

O próprio leitor angolano, aliás, como afirma Helena R iaúzova ${ }^{28}$, faz hoje uma revisão crítica dos aspectos concernentes à literariedade dos textos produzidos durante a luta de libertação nacional ou nos anos sucessivos. Tal revisão crítica diz respeito sobretudo à chamada "poesia de luta dos guerrilheiros" 29 , ou seja a poesia gerada a partir do contexto da luta armada, cujos autores eram em geral os próprios combatentes. 0 momento solicitava uma literatura que não se detivesse muito nos aspectos formais, mas que apoiasse e sustentasse, através de conteúdos politicamente revolucionários, o esforço de toda a nação na luta pela independência. Escritores e leitores haviam estabelecido uma espécie de pacto tácito neste sentido, onde todos atuavam no processo vital de transformação da sociedade. Tentou-se "democratizar" a poesia, código artístico de elite, através de uma simplificação das estruturas e da linguagem, de modo que os textos pudessem chegar a um público mais vasto.

Nos últimos anos, segundo a estudiosa, assistimos em Angola a um interessante processo de "transição do leitor de massa para o leitor de elite, aqui entendido como pessoa culta, capaz de apreciar devidamente a criação literária mais complexa quer do ponto de vista do conteúdo quer do ponto de vista da forma" ${ }^{30}$.

As razões deste fenômeno devem ser individuadas no aumento quantitativo do índice de alfabetizados e, sobretudo, na especialização qualitativa, na melhor formação destes leitores, que exigem hoje um produto artístico mais elaborado e refinado (ocorreu de fato um incremento do ensino universitário em Angola depois de 1976). Os próprios escritores maturaram um enfoque diverso em relação às suas obras, com uma maior atenção aos aspectos formais do texto.

\footnotetext{
Cf. Helena Riaúzova, op., cit., pp.11-28.

Ibidem.

Ibidem, pp. 22-23.
} 
Neste sentido, Costa Andrade demonstra uma lúcida e quase impiedosa percepção dos riscos e das limitações conexas ao fazer poesia ligada à praxis, relendo de forma rigorosa toda a sua obra precedente:

Está fora de causa que os meus livros e a minha obra vão pertencendo sempre cada vez mais a uma franja das coisas escritas para se limitarem ao tempo do seu aparecimento. Farei um esforço para mudar e juntar-me aos novos meios de locomoção... Não posso continuar a pisar com os pés o meu chão de exílio, que infelizmente continua presente em meu interior ${ }^{31}$.

Constatamos que a fase mais recente da sua poesia è de fato diversa da produção anterior e que isto ocorre também em função das transformações ocorridas na sociedade. É uma poesia com temáticas e formas mais atuais, temáticas vividas como uma nova forma de compromisso civil porque, como afirma o poeta, "o empenho não é só o da arma pela liberdade, mas também a capacidade de transformar a liberdade em amor e igualdade"32.

Em outras palavras, o poeta anuncia que a poesia-voz-coletiva cede o lugar ao um canto mais íntimo e pessoal. Chegou o tempo em Angola da poesia que é gratuidade, liberdade de linguagem, revelação do ser no mundo, "símbolo ou palavra/calada na cave nua da tua solidão"33. Sem trair ou distrair-se dos problemas que ainda hoje afligem de forma tão dramática este país, a poesia e a literatura angolanas reivindicam outras linguagens para novos percursos de pesquisa, de indagação, de recuperação da memória, de reflexão sobre a cultura e as tradições conjugadas às transformações mais vastas que neste final de milênio estigmatizam nossa realidade. E Costa Andrade sente profunda e intimamente este apelo e o transforma em canto, em palavra.

Vale notar, neste sentido, a adoção do pseudônimo Wayovoka André para os livros de poemas Limos de lume, de 1989, e Memória de Purpura, de 1990, numa aparente intenção de camuflagem, talvez devido - como dissemos - à dificuldade de despojar-se da marca do poeta engajado que Ihe ficou embutida.

Mas o livro que marca definitivamente a nova fase é Lwini (crónica de um a mor trá gi co), em que o poeta retoma o lirismo amoroso, mas agora eivado de um sentimento de precariedade, de um amor vivido com todos os seus códigos de seivas, de peles, de perdas, de mortes, em que a palavra - para contornar e abranger toda a complexidade desse sentir - deve fluir como água, como onda de ressaca que arrasta o leitor para a página, para a vida.

\footnotetext{
Comunicação pessoal do autor (20 de janeiro de 1990).

Entrevista feita por Anna Maria Farabbi, 27 de abril de 1989.

Costa Andrade, Os sentidos da pedras, cit., p.17.
} 


\title{
Descrever é sem palavras \\ sem traços desenhos impossíveis \\ pianos ou cordas sonoras \\ ver-te sem azul maior \\ que o horizonte porque és \\ estás e já te expandes infinita \\ sem palavras sem som sem \\ desenho menor que o horizonte ${ }^{34}$
}

O livro é coeso e unitário, parece na verdade conter um único poema espraiado pelos versos unidos por enj ambement: um imbricado no outro, como as ondas do mar, como os corpos confundidos no amor. As próprias metáforas estão ligadas ao mundo marinho, insondável, misterioso, mas também incessante, desmedido, solar, aberto à perscrutação dos olhos: "tempestades", "âncora", "praia matinal", "mar", "algas marinhas", "espuma", “onda", “concha”, "rochedo", “areal”, "navegação".

A linguagem é altamente metafórica, oposta àquela utilizada pelo poeta na fase precedente. Agora é o leitor que deve realizar um esforço para penetrar no universo complexo e plurivalente do poema. Neste livro o autor conseguiu um máximo de essencialidade e depuração, num ritmo que arranha e acalenta, que se contém e se espraia, modulado por um sentimento que conjuga, como afirma o poeta, "os amores amados com a procura do amor a amar".

\author{
Onde está a lavra? \\ quero mostrar o milho \\ às crianças órfãs \\ ensinar uma fábula antiga \\ em que os homens falavam \\ os olhos baços \\ perguntam de um tempo velho \\ o que quer dizer viver? \\ o braço que não tem \\ para agarrar o sol \\ também não pede a palavra \\ porque a guerra é surda \\ e muda \\ nem o fogo entende a chuva \\ só a morte ama a morte \\ contas sem fim de um rosário
}

Costa Andrade, Lwini (crónica de um amor trágico), Porto, União dos Escritores Angolanos, 1991, p.23. 
liana inquebrável que dói

mas acalenta e cega ${ }^{35}$

O poeta atingiu pois a densidade que toda sua produção anterior- de poeta engajado - deixava entrever pelas entrelinhas de um lirismo que ele conscientemente sacrificava em nome de um ideal. Costa Andrade hoje modula mais livremente palavra e voz para essa fragrância indefinível, essa audácia, essa memória, "essa forma admirada de um carinho" que é canto de um tempo - apesar de tudo - também de poesia.

\section{R eferências Bibliográficas}

\section{DO AUTOR: \\ POESIA}

Terra das acácias rubras, Lisboa, Casa dos Estudantes do Império, 1961.

Tempo angolano em Itália, São Paulo, Felman - Rego, 1963.

Armas com poesi a e uma certeza, Cazombo, M .P.L.A. F rente Leste, 1973 (E dição policopiada: 500 ex.).

Poesia com armas, Lisboa, Sá da Costa, 1975, 1a ed.; Lisboa/Luanda, Sá da Costa/U.E.A., 1978, 2a ed.; Lisboa/Luanda, Sá da Costa/U.E.A., 1979, 3ạ ed. ; Luanda, U.E .A., 1980, 4ạ ed.

O regresso e o canto, Lobito, Capricórnio, 1975.

O caderno dos heróis, Luanda, U.E.A., 1977, 1ae ed.; Luanda, U.E.A., 1978, 2a ed.; Luanda, U.E.A., 1980, 3a ed.

No velho ninguém toca - poema dramático, Lisboa/Luanda, Sá da Costa/U.E .A., 1979. O país de Bissalanka, Lisboa/L uanda, Sá da Costa/U.E.A., 1980.

O Cuneme corre para o sul, Luanda, U.E.A., 1981.

Ontem e depois, Lisboa/L uanda, E dições 70/U.E.A., 1985.

Falo de amor por amar, Luanda, U.E.A., 1985.

Os senti dos da pedra, Porto/L uanda, E ditora Asa/U.E.A., 1989.

Lwini (crónica de um amor trágico), Luanda, União dos Escritores Angolanos, s.d.

\section{OBRAS DE WAYOVOKA ANDRÉ (PSEUDÔNIMO DO AUTOR)}

Limos de lume, Luanda/Porto, E diçoes ASA/U.E.A., 1989.

Memórias de Purpura, Porto, Lito Tipo/U.E.A., 1990.

$35 \quad$ Op. cit., p.29. 


\section{PROSA}

Estórias de Contratados - contos, Lisboa/L uanda, E dições 70 /U.E .A., 1980.

Lenha seca - fábulas, Lisboa/L uanda, Sá da Costa/U.E .A., 1986.

\section{ENSAIOS}

Literatura angolana (Opiniões), Lisboa/L uanda, E dições 70/U.E.A., 1980.

"A política como poética", in Lavra \& Oficina, Luanda, 10/1985, p. 11.

“O grande desafio ganho", in Lavra \& Oficina, Luanda, U.E.A., 10/11/1985, p.8.

\section{SOBRE O AUTOR:}

ABRANCHES, Henrique, "Prefácio", in Literatura Angolana (Opiniões), Lisboa/Luanda, Edições 70/U.E.A., pp. 11-14.

ANDRADE, Mário Pinto de, "O Canto Armado do Povo Angolano", in Poesia com armas, Lisboa, Sá da Costa, 1975, pp. 1-18.

CHALENDAR, Pierrette et Gérard, "Politique - La fable comme genre littéraire: À propos de Lenha Seca de Costa Andrade", in Estudos Portugueses e Africanos, Campinas, $n^{\circ}$ 16, 1990.

DAVIDSON, B asil, “P refácio", in No vel ho ninguém toca, L isboa/L uanda, Sá da Costa/U.E .A., 1978, pp.3-9.

OLIVEIRA, Vera Lúcia de, "Transformações na Literatura Angolana", Revista de Letras, São Paulo, Universidade Estadual Paulista, 1992, pp.191-198.

PEPETE LA, “Prefácio”, in Estórias de Contratados, Lisboa/L uanda, U.E .A ./E dições 70, 1980, pp.11-14.

PEREIRA, Aristides, “À guisa de prefácio”, in O país de Bissalanka, Lisboa/Luanda, Sá da Costa/U.E.A., 1980, pp. 3-5.

RUI, Manuel, "R equiem para um homem", in Lavra \& Oficina, Luanda, n.1, 2 e 3, Luanda, 1981, p. 8.

SIM ÕES, M anuel G., "Formas de transmissão oral em 'E stórias de Contratados”“, in J ornal de Angola, 18/07/1989, p. 11. 
